\title{
Ecological and reproductive aspects of Neoechinorhynchus pimelodi Brasil-Sato \& Pavanelli (Eoacanthocephala, Neoechinorhynchidae) of Pimelodus maculatus Lacépède (Siluroidei, Pimelodidae) of the São Francisco River, Brazil
}

\author{
Marília de C. Brasil-Sato ${ }^{1}$ \\ Gilberto C. Pavanelli ${ }^{2}$
}

\begin{abstract}
Ecological and reproductive aspects of Neoechinorhynchus pimelodi Brasil-Sato \& Pavanelli, 1998, in Pimelodus maculatus Lacépède, 1803 collected in the São Francisco river during periods of drought (July 1995 and 1996) and floodings (January 1996 and 1997) of this river basin are provided. In tropical regions where the amount of rainfall alters the hydrological regimen of limnological systems water temperature has not had an important role in infections of $N$. pimelodi in $P$. maculatus. Prevalence was somewhat higher during drought periods. Intensity of infection varied slightly between collecting periods. Mature male and female acanthocephalans were present in all periods. Females were predominant. Mature females were present in higher numbers during flooding periods with a corresponding decrease in juvenile acanthocephalans. Recruitment and constant losses of $N$. pimelodi seem to be controlled by transmission mechanisms independently of density. Mechanisms may consist of infected prey availability (potential intermediate hosts) and changes of preferred alimentary items in the diets of juvenile and mature P. maculatus.

KEY WORDS. Acanthocephala, Neoechinorhynchus pimelodi, Pimelodus maculatus, ecology, reproduction
\end{abstract}

There are no published works in Brazil which refer to the populational dynamics of fish parasites. This is especially true of acanthocephalans. Research work on populational dynamics of neoechinorhynchid acanthocephalans in fresh water fish of temperate countries have shown seasonal aspects in the life cycles of these parasites. This is chiefly due to oscillations in water temperature. In the present paper aspects of ecology and reproduction of acanthocephalans in fresh water fish are analysed within a tropical geographical distribution. The lotic system of the São Francisco river basin is basically altered by rainfall variations which characterise flooding and drought periods.

\section{MATERIAL AND METHODS}

Pimelodus maculatus Lacépède, 1803, "mandi-amarelo", were collected in the São Francisco river, state of Minas Gerais, Brazil, downstream the Três Marias reservoir. In this lotic environment collections were carried out in July 1995 and

1) Departamento de Biologia Animal, Universidade Federal Rural do Rio de Janeiro. Caixa Postal 74539, 23851-970 Seropédica, Rio de Janeiro, Brasil.

2) Núcleo de Pesquisa em Limnologia, Ictiologia e Aqüicultura, Universidade Estadual de Maringá. 87020-900, Maringá, Paraná, Brasil. 
1996, rainless and drought periods; and in January 1996 and 1997 with $127 \mathrm{~mm}$ and $331.8 \mathrm{~mm}$ rainfall, respectively. Data for drought periods were: average water temperature $22.4^{\circ} \mathrm{C}$; electric conductivity $48 \mu \mathrm{S} / \mathrm{cm}$; $\mathrm{pH} 7.1$; dissolved oxygen $6.8 \mathrm{mg} / 1$; alkalinity $0.49 \mathrm{mEq} / \mathrm{l}$; hardness $22.02 \mathrm{mg} / \mathrm{l}$. Data for flooding periods were: average water temperature $24.4^{\circ} \mathrm{C}$; electric conductivity $48.5 \mu \mathrm{S} / \mathrm{cm} ; \mathrm{pH} 6.4$; dissolved oxygen $2.5 \mathrm{mg} / \mathrm{l}$; alkalinity $0.41 \mathrm{mEq} / \mathrm{l}$ and hardness $20.02 \mathrm{mg} / \mathrm{l}$ (data given by the Codevasf/Três Marias limnological team). Fish were identified according to BRITSKI et al. (1984), kept in tanks with running water from the same limnological system, slaughtered and necropsied at the Codevasf laboratory. Standard length $(\mathrm{cm})$, weight $(\mathrm{g})$ and sex were registered. The digestive system of each fish was separated in a Petri dish with a $0.65 \%$ physiological saline solution and dissected under a stereomicroscope. Acanthocephalans were placed in distilled water and kept for 20 hours in a refrigerator at $4^{\circ} \mathrm{C}$ for eversion of proboscis and copulatory bursa. They were then fixed in AFA (alcohol $70^{\circ} \mathrm{GL}$ - formalin - glacial acetic acid), transferred to alcohol $70^{\circ} \mathrm{GL}$, stained with Mayer's carmine, dehydrated in ethanol, cleared in creosote and mounted in Canadian balsam. Species were determined according to BRASIL-SATO \& PAVANELLI (1998). Acanthocephalans were classified according to maturation stages with following nomenclature: juvenile male (immature - gonads and seminal ducts still in process); juvenile female (immature reproductive system still in process and absence of ovarian balls); mature male (reproductive system complete with seminal duct); female with ovarian balls (almost mature female, without eggs); mature female (female with ovarian balls and eggs with acanthor or completely filled with eggs with acanthor). Definitions of ecological terms followed MARGOLIS et al. (1982). $G$ log-likelihood test evaluated the prevalence of $N$. pimelodi with regard to sex of $P$. maculatus. Student's $t$, Mann-Whitney and Wilcoxon's $U$ tests for two samples evaluated possible influence of sex of $P$. maculatus on the intensity of parasite infection. Linear correlation $r$ was computed between mean of standard length classes and prevalence and between standard length and infection intensity (ZAR 1984; SOKAL \& ROHLF 1995). Quattro Pro for Windows 5.0 was used for Student's $t$ and correlation $r$ tests. Significance level for above tests was $p<0.05$. Harvard Graphics 4.0 was used for graphs.

\section{RESULTS}

\section{Infected Pimelodus maculatus analysed according to collecting periods}

During the collecting period 239 P. maculatus were examined. Standard length varied from $11.0 \mathrm{~cm}$ to $32.5 \mathrm{~cm}$. Ninety-four (39.33\%) were infected by Neoechinorhynchus pimelodi. In the drought period 54 fish (46.55\%) were found infected, whereas 40 fishes $(32.52 \%)$ were found infected in the flooding period. While in the drought period standard length of infected $P$. maculatus varied from $11.5 \mathrm{~cm}$ to $23.5 \mathrm{~cm}$, in flooding period it varied from $13.5 \mathrm{~cm}$ to $24.5 \mathrm{~cm}$. Mean standard lengths of examined and infected $P$. maculatus according to collection periods are shown in table I. 
Table I. Prevalence, average infection intensity and dispersion of Neoechinorhynchus pimelodi in Pimelodus maculatus, collected in July 1995 and 1996 and January 1996 and 1997 in the São Francisco river, Três Marias, Minas Gerais, Brazil. (SE) Mean Standard Error, (t) total, $(\mathrm{m}: \mathrm{f})$ male and female parasites analysed, (SL) Standard Length.

\begin{tabular}{lcccccccc}
\hline $\begin{array}{c}\text { Collecting } \\
\text { period }\end{array}$ & $\begin{array}{c}\text { Number } \\
\text { examined }\end{array}$ & $\begin{array}{c}\text { Number Prevalence Mean infection } \\
\text { infected } \\
(\%)\end{array}$ & & $\begin{array}{c}\text { Variance } \\
\text { intensity } \pm \text { SE } \\
\text { Mean }\end{array}$ & $\begin{array}{c}\text { Number of } \\
\text { acanthocephala } \\
\text { t(m:f) }\end{array}$ & $\begin{array}{c}\text { Mean SL of } \\
\text { infected fish } \\
(\mathrm{cm}) \pm \text { SE }\end{array}$ & $\begin{array}{c}\text { Mean SL of } \\
\text { examined fish } \\
(\mathrm{cm}) \pm \text { SE }\end{array}$ \\
\hline Drought 1995 & 57 & 24 & 42.10 & $4.8 \pm 0.8$ & 3.84 & $116(50: 52)$ & $16.5 \pm 0.6$ & $16.8 \pm 0.4$ \\
Flooding 1996 & 67 & 23 & 34.32 & $4.9 \pm 1.1$ & 5.62 & $114(43: 58)$ & $19.8 \pm 0.5$ & $21.2 \pm 0.3$ \\
Drought 1996 & 59 & 30 & 50.84 & $4.9 \pm 0.9$ & 5.31 & $148(32: 80)$ & $19.5 \pm 0.4$ & $19.9 \pm 0.3$ \\
Flooding 1997 & 56 & 17 & 30.35 & $3.5 \pm 1.0$ & 5.67 & $60(13: 47)$ & $19.8 \pm 0.6$ & $21.5 \pm 0.4$ \\
\hline Total & 239 & 94 & 39.33 & $4.6 \pm 0.4$ & 4.95 & $438(138: 237)$ & $18.8 \pm 0.3$ & $19.9 \pm 0.2$ \\
\hline
\end{tabular}

\section{Prevalence and mean intensity of infection and dispersion of $N$. pimelodi by collecting period and size class of $P$. maculatus}

The prevalence of $N$. pimelodi during the whole period varied from $30.35 \%$ to $50.84 \%$ in $P$. maculatus. In drought periods values were higher. Mean infection intensity varied slightly between periods. It was less intense in the last flooding. Mean standard length of examined hosts was higher in flooding periods and coincides with lower prevalences. Table I shows prevalence, mean infection intensity and dispersion of $N$. pimelodi of $P$. maculatus during drought and flooding periods in the São Francisco river basin.

There was no significant difference neither in the prevalence of $N$. pimelodi in male $P$. maculatus (37\% or 46 out of 124 examined specimens) and female $P$. maculatus ( $41 \%$ or 48 out of 115 examined specimens) by collecting periods $(\mathrm{G}=3.05 ; 0.05<\mathrm{p}<0.10$ during drought; $\mathrm{G}=0.028,0.75<\mathrm{p}<0.90$ in floodings) nor during the whole period of collecting of fish $(\mathrm{G}=0.53 ; 0.25<\mathrm{p}<0.50)$. There was no significant difference neither in mean intensity of infection of $N$. pimelodi by sex $(4.76 \pm 0.69$ and $4.56 \pm 0.71$ during drought and flooding respectively, $t=-0.19$, $\mathrm{p}=0.84)$ nor in infection intensity of $N$. pimelodi among male and female $P$. maculatus in the drought period $(\mathrm{Z}=-0.97 ; 0.20<\mathrm{p}<0.50)$, in flooding period $(Z=0.24 ; p>0.50)$ and during the whole collecting period $(Z=-0.65 ; p>0.50)$.

The hosts' standard length class with highest prevalence and with the greatest number of acanthocephalans was $16.0-18.0 \mathrm{~cm}$. Maximum number of acanthocephalans $(\mathrm{n}=23$ ) was collected from a $16.0 \mathrm{~cm}$ and $62 \mathrm{~g}$ female during the flooding period. No fish over $24.5 \mathrm{~cm}$ was found infected. Figure 1 show prevalence and mean infection intensity of $N$. pimelodi in the respective standard length classes of $P$. maculatus. A marked negative significant correlation was found between prevalence and standard length classes $(\mathrm{r}=-0.82 ; \mathrm{p}<0.001)$. Positive slight significant correlation was found between infection intensity and standard length $(r=0.14$; $0.02<\mathrm{p}<0.05$ ) of $N$. pimelodi in P. maculatus.

Sampling of collections showed negative binomial distribution of these parasites [(variance $\div$ average $)=4.95]$. Superdispersion of $N$. pimelodi occurred in all the collecting periods. Lowest value was found in the drought season (July 1995) according to the greatest number of parasites collected. Mean standard length of fish examined in this collection period was $16.8 \mathrm{~cm}$ while that of infected fish was 
$16.5 \mathrm{~cm}$. Marked superdispersion occurred in the flooding period (January 1996 and 1997) according to the lowest number of parasites collected and of infected fish. Mean standard length of $P$. maculatus examined was $21.5 \mathrm{~cm}$ while that of infected P. maculatus was $19.8 \mathrm{~cm}$ (Tab. I).

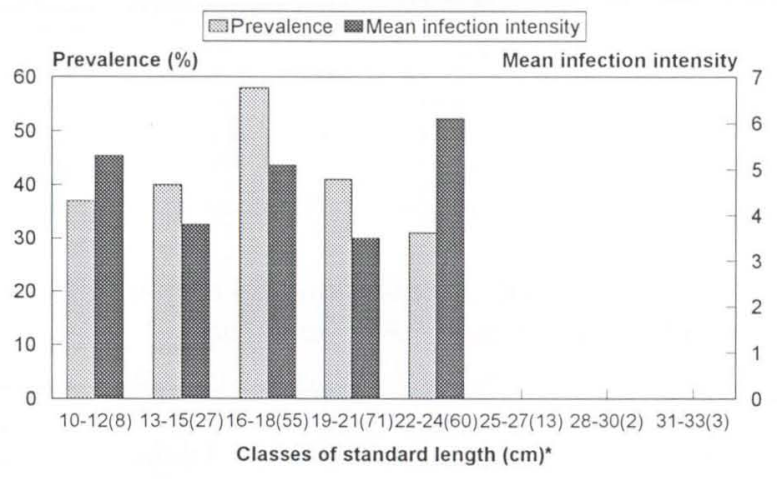

*Classes are followed by number of examined fishes in brackets.

Fig. 1. Prevalence and mean infection intensity of Neoechinorhynchus pimelodi in Pimelodus maculatus, according to classes of standard length, collected in July 1995 and 1996 (drought) and in January 1996 and 1997 (flooding) in the São Francisco river, Três Marias, Minas Gerais, Brazil.

\section{Sexual proportion and maturation of $N$. pimelodi in $P$. maculatus in drought and flooding periods}

Sexual proportion was lowest in the drought period with 1:1.0 (July 1995) and 1:2.7 (July 1996) for males and highest in the flooding period with 1:1.4 (January 1996) and 1:4.4 (January 1997) which indicated the great number of females collected. Female acanthocephalans comprise $64.6 \%$ of samples and were found during all collecting periods. Mature females (59.8\%) were predominant when compared to females with ovarian balls $(28.3 \%)$ and female juveniles $(11.9 \%)$. Females with ovarian balls were constant in drought and flooding periods. Males were also present in all periods (Tab. II, Fig. 2). There was a positive significant correlation between percentage of mature males and an increase of mature females $(r=0.99 ; p<0.001)$, while there was a negative one between number of mature females and male and female juvenile acanthocephala $(\mathrm{r}=0.98 ; \mathrm{p}<0.001)$ infecting $P$. maculatus in the drought and flooding periods.

Table II. Sex structure and maturation of Neoechinorhynchus pimelodi in Pimelodus maculatus, collected in July 1995 and 1996 and in January 1996 and 1997 in the São Francisco river.

\begin{tabular}{|c|c|c|c|c|c|c|c|c|}
\hline \multirow[t]{2}{*}{ Collecting period } & \multicolumn{2}{|c|}{ Total $(\%)$} & \multirow[t]{2}{*}{ Sex ratio } & \multicolumn{2}{|c|}{ Males (\%) } & \multicolumn{3}{|c|}{ Females (\%) } \\
\hline & Males & Females & & Juveniles & Mature & Juveniles & Ovarian balls & Mature \\
\hline Drought 1995 & 48.9 & 51.1 & $1: 1.0$ & 37.8 & 62.2 & 15.0 & 34.0 & 51.0 \\
\hline Flooding 1996 & 41.8 & 58.2 & $1: 1.4$ & 52.6 & 47.4 & 24.4 & 30.2 & 45.4 \\
\hline Drought 1996 & 26.5 & 73.5 & $1: 2.7$ & 18.9 & 81.1 & 6.7 & 29.3 & 64.0 \\
\hline Flooding 1997 & 18.6 & 81.4 & $1: 4.4$ & 0.0 & 100.0 & 2.2 & 18.2 & 79.6 \\
\hline
\end{tabular}




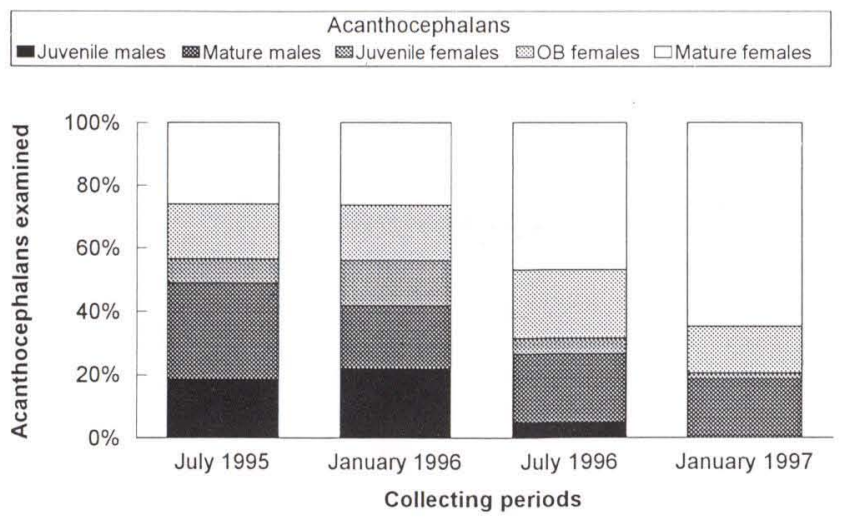

Fig. 2. Maturation of Neoechinorhynchus pimelodi of Pimelodus maculatus, collected in July 1995 and 1996 (drought) and in January 1996 and 1997 (flooding) in the São Francisco river, Três Marias, Minas Gerais, Brazil. (OB Female) Female with ovarian balls.

\section{DISCUSSION}

Neoechinorhynchus pimelodi Brasil-Sato \& Pavanelli, 1998, was recently described in Pimelodus maculatus of the São Francisco river. It is not known whether the parasite infects other species of fish in this limnological system and/or whether its geographical distribution is restricted to this river basin.

In temperate climate waters where the majority of studies on seasonal population dinamycs of neoechinorhynchid acanthocephalans were carried out, the cycles of the parasites reflect the seasonal changes on water temperature (CHUBB 1982; AMIN 1986; LASEE 1989). When maturation of adult acanthocephalans or production of eggs are seasonal, transmission to intermediate host is usually restricted to a few periods during the year. This is due to limited time of survival and infectability of eggs. Likewise, if conditions permit the production of eggs during the whole year, transmission may occur many times during the year since there is no seasonal cycle in populations of intermediate hosts (KENNEDY 1985). Slightly different values of prevalence and mean intensity of infection, maturing females at constant levels, mature females with eggs containing acanthors and juvenile acanthocephalans during the whole collecting period show that a small variation in temperature $\left(22.4^{\circ} \mathrm{C}\right.$ in droughts and $24.5^{\circ} \mathrm{C}$ in floodings) along with other physical and chemical changes of water s did not affect the transmission of $N$. pimelodi in P. maculatus in the São Francisco river. Although variations were insignificant, there was a continuous transmission of $N$. pimelodi in mandis. This fact is in accordance to the infection model of Acanthocephalorhynchoides cholodkowskyi (Kostylev, 1928) in Schizothorax intermedius found by BAUER \& KARIMOV (1990) in its Central Asian habitat with constant water temperature. Neoechinorhynchus saginatus did not show any seasonal pattern infection in Semotilus corporalis (Mitchill). There was a continuous supply of infected intermediate hosts (MUZALL \& BULLOCK 1978).

According to BAUER \& KARIMOV (1990) parasites in habitats with constant water temperature may be divided into group that infects fishes directly by swim- 
ming larvae (oncomiracidia, cercariae, etc.) and into group that infects fishes by means of food taken. Parasites of the last group (as in the case of Acanthocephala transmission) may increase when fish eat more food. Results at the present work show approximate values of mean infection intensity in both periods (drought and flooding) and slightly higher prevalence in the drought periods. During the dry period, however, a higher number of smaller $P$. maculatus were necropsied, including the class of standard length with $16.0-18.0 \mathrm{~cm}$. In the last flooding a lower number of fish of this length class were examined. On the other hand, during flooding period over $19.0 \mathrm{~cm}$ hosts were examined, larger than those examined in the dry period (Fig. 3). Since negative correlation is clear and the greater hosts conserve fewer Acanthocephala, the lower prevalences of parasites during these periods have been satisfactorily explained.

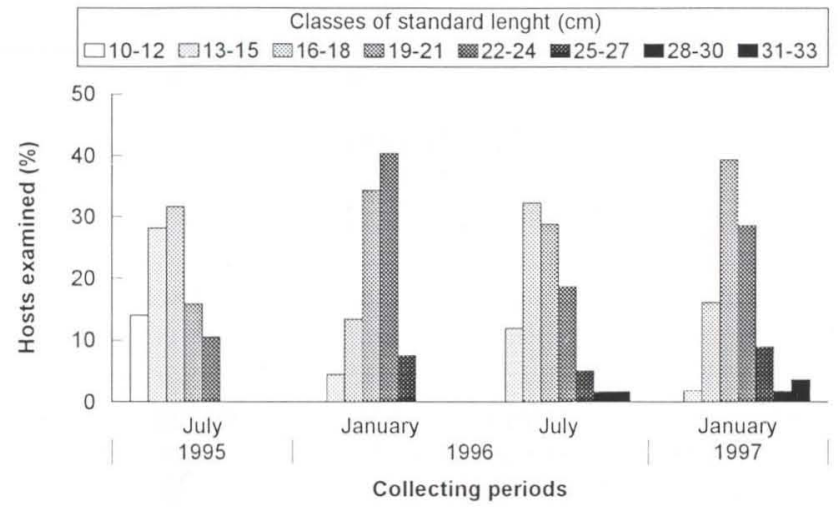

Fig. 3. Percentage distribution of Pimelodus maculatus, analysed according to classes of length, collected in July 1995 and 1996 (drought) and in January 1996 and 1997 (flooding) in the São Francisco river, Três Marias, Minas Gerais, Brazil.

The majority of infrapopulations of acanthocephalans in fish show a dynamic balance between recruitment and loss of parasites. A consensus has been established that, besides temperature, the most important determinants affecting the establishment and development of acanthocephalans in final hosts are the availability of intermediate infected hosts and infecting larvae, diet and feeding behaviour of hosts (KENNEDy 1985). Pimelodus maculatus was classified as an euriphagic species (BASILE-MARTINS et al. 1986), a name associated to the wide variety of food items in its diet (Menezes \& MENEZES 1946; BAsile-Martins et al. 1971; AgostinHo 1985). Changes in diet composition and in the feeding habit of $P$. maculatus of different lengths and during the reproductive period were observed. According to BAsile-MARTins et al. (1971), the diet of P. maculatus measuring $100 \mathrm{~mm}$ to $199 \mathrm{~mm}$ consisted of $22.9 \%$ algae, $21.0 \%$ insects, $17.9 \%$ microcrustaceans and $4.2 \%$ fish. Specimens measuring $200-299 \mathrm{~mm}$ reduced algae and microcrustaceans to $13.4 \%$ and $9.2 \%$ respectively and increased insects and fish to $26.8 \%$ and $8.4 \%$ respectively. Algae and microcrustaceans were reduced in approximately $50 \%$. Fish were increased in $100 \%$. A very slight change occurred in insects. BASILE-MARTINS 
et al. (1986) showed that diet variation of P. maculatus during development is mainly reflected in the high exploitation of microcrustaceans and molluscs by juveniles (one year) and of fish by adults (two to six years). The same authors found a great number of $P$. maculatus with empty stomachs in the hot season. The existence of diet alteration was suggested because of physiological changes in fish during the reproductive period. In the middle River Paraná studies by BONETTO et al. (1963) on the P. maculatus revealed diets with planktonic, nektonic and benthonic elements. BASILE-MARTINS et al. (1971) obtained the same results. AGOSTINHO (1985) also found insects, mainly Chironomidae, microcrustaceans (Cladocera), molluscs, fish and vegetation remains (seeds) as predominant items in these fish in the Paraná river. SOUZA \& TORRES (1984) indicated predominant predation of molluscs by $P$. maculatus in the São Francisco river.

Ostracods, copepods and larvae of Megaloptera have been cited as intermediate hosts for neoechinorhynchid acanthocephalans (SCHMIDT 1985; LASSIERE 1988; LASEE 1989; DEZFULi 1996). All these groups of organisms (potential intermediate hosts) were found in the $P$. maculatus during necropsy. They were available in the São Francisco basin throughout the whole period as food items of the fish' diets. Paratenic hosts (larvae of Megaloptera and molluscs) and secondary optional intermediary hosts (hirudins) were registered in some known cycles of neoechinorhynchids (SCHMIDT 1985; DEZFULI 1996). The use of insect larvae, ostracods and molluses in the diet of $P$. maculatus hightens the transmission of $N$. pimelodi mainly within the length classes of the younger fish. The chiefly piscivorous alimentary habit or the alimentary abstinence during the reproductive period in older P. maculatus possibly affected the fixation of new acanthocephalans by decrease or by non-predation of intermediate and/or possible paratenic hosts. This fact justified a decrease of prevalence in acanthocephalan in the upper standard length classes (Fig. 1). The selective behaviour of the P. maculatus in the different growth phases favours transmission which is capable of maintaining recruitment in the dry and rainy periods with lesser percentage of juvenile males and females than that of more mature acanthocephalans. However, fewer juveniles during periods with greater numbers of mature females (negative significant correlation) (Fig. 2) may be the effect of space restriction or of a better use of available resources in the host. The most important role of these acanthocephalans might be the release of eggs by mature females.

The predominance of mature females acanthocephalans over mature males was strongly marked in the last collecting and flooding period (January 1997), when infected hosts were larger and some mandis were in the spawning period. Notwithstanding the balance in sexual rate (male/female) corresponds to instantaneous rates of mortality of male and female parasites, in the life cycle of the acanthocephalans in the final host the disparity in the life span of males and females justifies the predominance of females over males (DOBSON \& KEYMER 1985).

Post-cyclic transmission also occurs among acanthocephalans (LASSIERE \& CROMPTON 1988). Although it is known that P. maculatus have a piscivorous feeding habit in the adult phase (larger size), the prevalence of $N$. pimelodi decreased considerably in the larger fish. No mandi over $24.5 \mathrm{~cm}$ was infected. Although the 
existence of $N$. pimelodi in other fish of the São Francisco basin is unknown, these data show the existence of basic transmission mechanism through the ingestion of intermediate and/or potential paratenic hosts (larvae of insects and molluscs) in mandis. This is done chiefly by smaller ones throughout the whole year. Acquired immunity may also explain why large fishes are less infected and/or are without parasites. Nevertheless, more studies on fish parasites should be undertaken for other data in this hydrological system.

Recruitment and maturation of $N$. pimelodi occur in all drought and flooding periods. There is no seasonal cycle. Superdispersion does not seem to have affected the mandis. Analyses of histological sections of intestines with fixed acanthocephalans showed an absence of damages such us fibrosis, inflammation, cell necrosis, caused by these parasites (unpublished). Water temperature and changes in the hydrological regimen in drought and flooding periods did not affect the rate of parasite losses. Data indicate existence of a transmission process of acanthocephalans independently of density and affecting the stability of infrapopulations of $N$. pimelodi in the P. maculatus of the São Francisco river. According to LASSIERE \& CROMPTON (1988) it is possible that infection intensity in the predator may be the result of prevalence of acanthocephalan in the prey. It is possible that more complex vital cycles involving post-cyclic transmission and additional arthropod hosts have an important role in the stability of parasite suprapopulation.

Future research will complement the study of ecology and reproduction of $N$. pimelodi. It is aim will be the identification of its potential intermediate hosts and the relationship between parasite and final and intermediate hosts in the hydrographic basin of the São Francisco river.

ACKNOWLEDGEMENTS. The authors would like to thank the Biologist Yoshimi Sato and Codevasf, Três Marias, Minas Gerais, Brazil, for the collection and identification of fish and for the help during this research; to the Biologist Ricardo M. Takemoto, Prof. Marion H. Machado (both from the Universidade Estadual de Maringá, Maringá, Paraná, Brazil) and Dr. Jorge Eiras (Universidade do Porto, Porto, Portugal) for the reading of manuscript and suggestions.

\section{REFERENCES}

Agostinho, A.A. 1985. Ecologia de populações de peixes no reservatório de Itaipu nos primeiros anos de sua formação. Terceira etapa. Convênio Fuem-Surehma/Itaipu-Binacional, 508p.

AMIN, O.M. 1986. Acanthocephala from lake fishes in Wisconsin: host and seasonal distribution of species of the genus Neoechinorhynchus Hamann, 1892. Jour. Parasitol. 72: 111-118.

Basile-Martins, M.A.; H.M. Godinho; H.R Chaves \& J.M.B. BarkeR. 1971. Considerações preliminares sôbre o regime alimentar do mandi Pimelodus maculatus Lac. (Pisces-Siluriformes). Ciência e Cultura 23 (supl.1): 270.

Basile-Martins, M.A.; M.N. Cipólli \& H.M. Godinho. 1986. Alimentação do mandi Pimelodus maculatus Lacépède, 1803 (Osteichthyes, Pimelodidae), de 
trechos dos rios Jaguari e Piracicaba, São Paulo - Brasil. Bol. Inst. Pesca, São Paulo, 13: 17-19.

Bauer, O.N. \& S.B. Karimov. 1990. Patterns of parasitic infections of fishes in a water body with constant temperature. Jour. Fish Biol. 36: 1-8.

BonetTo, A.A.; C. Pignalberi \& E. Cordiviola. 1963. Ecologia alimentaria del "amarillo" y "moncholo" Pimelodus clarias (Bloch) y Pimelodus albicans (Valenciennes) (Pisces, Pimelodidae). Physis, Buenos Aires. 24: 87-94.

Brasil-Sato, M. DE C. \& G.C. Pavanelli. 1998. Neoechinorhynchus pimelodi sp.n. (Eoacanthocephala, Neoechinorhynchidae) parasitizing Pimelodus maculatus Lacépède, "mandi-amarelo" (Siluroidei, Pimelodidae) from the basin of the São Francisco river, Três Marias, Minas Gerais, Brazil. Revta bras. Zool. 15 (4): 1003-1011.

BRITSKI, H.A.; Y. SATO \& A.B.S. RosA. 1984. Manual de identificação de peixes da região de Três Marias (Com chaves de identificação para os peixes da bacia do São Francisco). Brasília, Câmara dos Deputados, Coordenação de Publicação - Codevasf, Divisão de Piscicultura e Pesca, 143p.

CHUBB, J.C. 1982. Seasonal ocurrence of helminths in freshwatrer fishes. Part IV. Adult Cestoda, Nematoda and Acanthocephala. Adv. Parasit. 20: 1-193.

DezFuli, B.S. 1996. Cypria reptans (Crustacea: Ostracoda) as an intermediate host of Neoechinorhynchus rutili (Acanthocephala: Eoacanthocephala) in Italy. Jour. Parasitol. 82: 503-505.

DoBSON, A.P. \& A.E. KeYMER. 1985. Life history models, p.347-384. In: D.W.T. CROMPTON \& B.B. NiCKOL (Eds). Biology of the Acanthocephala. Cambridge, Cambridge University Press, 519p.

KENNEDY, C.R. 1985. Regulation and dynamics of acanthocephalan populations, p.385-416. In: D.W.T. CROMPTON \& B.B. NicKOL (Eds). Biology of the Acanthocephala. Cambridge, Cambridge University Press, 519p.

LASEE, B.A. 1989. Seasonal population dynamics and maturation of Neoechinorhynchus pungitius (Acanthocephala: Neoechinorhynchidae) infecting brook stickleback, Culaea inconstans, from Sioux Creek, Wisconsin, U.S.A. Can. Jour. Zool. 67: 590-595.

LASSIERE, O.L. 1988. Host-parasite relationships between larval Sialis lutaria (Megaloptera) and Neoechinorhynchus rutili (Acanthocephala). Parasitology 97: 331-338.

LASSIERE, O.L. \& D.W.T. CROMPTON. 1988. Evidence for post-cyclic transmission in the life-history of Neoechinorhynchus rutili (Acanthocephala). Parasitology 97: 339-343.

Margolis, L.; G.W. Esch; J.C. Holmes; A.M. Kuris \& G.A. Schad. 1982. The use of ecological terms in parasitology (Report of an ad hoc Committee of the American Society of Parasitologists). Jour. Parasitol. 68: 131-133.

MENEZES, R.S. DE \& M.F. DE MENEZES. 1946. Notas sobre o regime alimentar de algumas espécies ictiológicas de água doce do nordeste. Rev. Brasil. Biol. 6: 537-542.

Muzzall, P.M. \& W.L. Bullock. 1978. Seasonal occurrence and host-parasite relationships of Neoechinorhynchus saginatus Van Cleave and Bangham, 1949 in the fallfish, Semotilus corporalis (Mitchill). Jour. Parasitol. 55: 1212-1217. 
SCHMIDT, G.D. 1985. Development and life cycles; p.273-305. In: D.W.T. CromPTON \& B. B. NICKOL (Eds). Biology of the Acanthocephala. Cambridge, Cambridge University Press, $519 \mathrm{p}$.

SoKAL, R.R. \& F.J. RoHLF. 1995. Biometry. USA, W.H. Freeman and Company, $3^{\text {rd }}$ ed., $887 \mathrm{p}$.

SOUZA, M.R.F. \& G.E. TorRES. 1984. Alimentação natural, specificidade alimentar e capacidade malacófaga de Pimelodus maculatus Lacépede, 1803 (Osteichthyes, Siluriformes, Pimelodidade) da Represa de Três Marias, MG. III Encontro Anual de Aqüicultura de Minas Gerais, Belo Horizonte, p. 16-18. ZAR, J.E. 1984. Biostatistical Analysis. Englewood, Prentice-Hall Inc., $2^{\text {nd }}$ ed., $476 \mathrm{p}$.

Recebido em 01.VIII.1997; aceito em 25.I.1999. 